\title{
microRNA-628 Inhibits the Proliferation of Acute Myeloid Leukemia Cells by Directly Targeting IGF-IR [Retraction]
}

Chen L, Jiang X, Chen H, Han Q, Liu C, Sun M. OncoTargets and Therapy. 2019;12:907-919.

The Editor and Publisher of OncoTargets and Therapy wish to retract the published article. Concerns were raised over alleged image duplication in Figures 2D, 4D and 5D with similar images from unrelated articles, specifically:

- Figure 4D, panel HL-60 NC siRNA appears to have been duplicated with a similar image in Figure 6B from $\mathrm{Li}$ et al, 2019 (https://doi.org/10.2147/CMAR.S210845).

- Figure 4D, panel THP-1 NC siRNA appears to have been duplicated with a similar image in Figure 5C from Wang et al, 2018 (https://doi.org/10.3892/or. 2018.6804).

- Figure 5D, panel HL-60 miR-NC appears to have been duplicated with a similar image in Figure 6E from Wang et al, 2019 (https://doi.org/10.3892/ijo.2019.4759).

- Figure 5D, panel HL-60 miR-628 mimics + pc-IGF -1R appears to have been duplicated with similar images from Figure 5C from Lv et al, 2019 (https:// doi.org/10.2147/OTT.S208263) and Figure 6D from Yun et al, 2019 (https://doi.org/10.2147/CMAR. S198615).

- Figure 5D, panel THP-1 miR-NC appears to have been duplicated with a similar image in Figure 4D from Zhao et al, 2018 (https://doi.org/10.3892/ijo. 2018.4615).

The authors did not respond to our queries and the Editor determined the findings of the study were no longer valid and advised for the article to be retracted.

Our decision-making was informed by our policy on publishing ethics and integrity and the COPE guidelines on retraction.

The retracted article will remain online to maintain the scholarly record, but it will be digitally watermarked on each page as "Retracted".

\section{Publish your work in this journal}

OncoTargets and Therapy is an international, peer-reviewed, open access journal focusing on the pathological basis of all cancers, potential targets for therapy and treatment protocols employed to improve the management of cancer patients. The journal also focuses on the impact of management programs and new therapeutic agents and protocols on patient perspectives such as quality of life, adherence and satisfaction. The manuscript management system is completely online and includes a very quick and fair peer-review system, which is all easy to use. Visit http://www.dovepress.com testimonials.php to read real quotes from published authors. 